Western University Scholarship@Western

Centre for the Study of International Economic Centre for the Study of International Economic

Relations Working Papers

Relations

1987

\title{
Regional Balance Sheets of Gains and Losses from National Policies
}

Rich Jones

John Whalley

Follow this and additional works at: https://ir.lib.uwo.ca/economicscsier_wp

Part of the Economics Commons

Citation of this paper:

Jones, Rich, John Whalley. "Regional Balance Sheets of Gains and Losses from National Policies." Centre for the Study of International Economic Relations Working Papers, 8708C. London, ON: Department of Economics, University of Western Ontario (1987). 
ISSN $\quad 0228-4235$

ISBN $\quad 0-7714-0869-2$

THE CENTRE FOR THE STUDY OF INTERNATIONAD. ECONOMIC RELATIONS

WORKING PAPER NO. $8708 \mathrm{C}$

REGIONAL BALANCE SHEETS OF GAINS AND

LOSSES FROM NATIONAL POLICIES

Rich Jones

John Whalley

This paper contains preliminary findings from research work still in progress and should not be quoted without prior approval of the author.

DEPARTMENT OF ECONOMICS THE UNIVERSITY OF WESTERN ONTARIO LONDON, CANADA

N6A $5 \mathrm{C} 2$ 


\title{
Regional Balance Sheets of Gains and Losses from National Policies
}

\author{
Rich Jones \\ Department of Economics \\ University of Western Ontario \\ London. Canada N6A 5C2 \\ and \\ John Whalley \\ National Bureau of Economic Research \\ Cambridge, Massachusetts, USA \\ and \\ Department of Economics \\ University of Western Ontario \\ London, Canada N6A $5 \mathrm{C} 2$
}

May 1987 


\section{Introduction}

Debates on the regional impacts of national government policies often focus on accounting exercises examining differences in taxes collected from and direct expenditures made in each region of a national economy; reglonal balance sheets. Among other deficiencies, balance sheet approaches treat regional effects of policies as the outcome of a zero-sum game in which net benefits sum to zero. They only capture the cash component of transactions between regions rather than wider impacts on regional welfare. They ignore indirect effects, such as changes in regions' terms-of-trade. And, the reference point for assessing regional gains or losses is taken to be a situation in which policies are absent, rather than the next best alternative for the region (such as leaving the Federation).

In this paper we present an alternative approach to the evaluation of regional effects of policies which avoids most of these problems, i.e. numerical regional general equilibrium modelling (see Jones and Whalley (forthcoming)). We describe a Canadian regional general equilibrium model which we have implemented using data for 1981, and present calculations of regional effects of national policies in Canada which illustrate the differences in approach. 
I . Problems with Regional Balance Sheets

Regional balance sheets can be thought of as attempts to assess regional gains or losses from national government policies through the comparison of direct regional benefits and costs. Reglonal benefits may include direct expenditures by national governments on regionally supplied goods and services, or cash transfers both to sub-national governments through revenuesharing schemes and to individuals located in particular regions. 1 Regional costs usually focus on taxes paid by consumers and producers within each region.

In Canada, the regional dimensions to policy debates have been especially important since Confederation (1867), and balance sheets have a long history. At the time of the Rowell-sirois royal commission, which led to the present system of equalization payments paid by the federal government to lower per capita income provinces, Mackintosh (1939) used such an exercise to argue that Canadian federalism was balanced across regions. More recently, in the debates on possible provincial separation, balance sheets were used by both the federal and Quebec governments to argue that Quebec would either lose or gain by taking such a step (see Leslie and simeon (1977)).

However, despite its widespread use the balance sheet approach has many problems. Even if taxes collected and

${ }^{1}$ Although commonly done, treating these equaliy in such a calculation is clearly inappropriate since in one case regional resources are purchased, and in the other national resources are transferred with no quid pro quo. 
expenditures made in various regions (either as intergovernmental transfers or direct government expenditures in the region) can be accurately measured and appropriately recorded, they represent only a part of the regional policy interplay within federal states. With many policies no interregional flow of funds occurs, and yet significant interregional impacts result. For instance, if a national tariff allows producers of manufactures in one region to sell them to consumers in other regions at gross-of-tariff prices, an interregional transfer between exporting and importing regions occurs. Many other policies, such as taxes, price controls, and regulatory policies also produce comparable interregional effects when producers and consumers are located in different regions. This, however, is not the only difficulty.

Accomodating interregional labour mobility into balance sheet calculations is also problematic. If one assumes, for instance, that labour is perfectly mobile interregionally, it is not possible to equate a particular group of individuals gaining or losing the effects by region. When one talks of a region gaining or losing from a particular national policy, the issue is whether one means the residents of the region before the policy change (including outward migrants), only those people remaining, or all of those located in the region after the change (including inward migrants).

Another difficulty is interregional asset ownership. Even if one argues that national policies only affect interregionally 
immobile factors of production, these factors may not be located in the same region as their owners. Residents in other regions, therefore, can be affected by national policies through their role as factor owners: Little or no data exists on interregional asset ownership patterns in any of the major OECD countries, making this especially difficult to take into account either in balance sheet or other approaches, including the general equilibrium model we report on later.

A further difficulty with balance sheet exercises is the implicit assumption that what one region gains from any national policy other regions lose, i.e., the policy impacts define a zero-sum game. Cooperation between regions in a federation may, in fact, produce a surplus (e.g. due to the gains from trade from the customs union in a federation) so that a positive rather than a zero-sum game is involved.

Balance sheet exercises also do not spell out the alternatives which are being considered to current arrangements when assessments of regional impacts of policies are being made. Especially important is the fact that any federation is a cooperative arrangement. What each region gains or loses from national policies in a federal arrangement should thus be evaluated relative to the next best alternative for that region--which may be leaving the federation. If the net effect of national policies on a region comes out negative in a balance sheet calculation, it does not necessarily follow that the region would be better of outside the federation. It is thus possible 
that while a region may be perceived as a loser from a balance sheet exercise, it is a gainer when its situation is evaluated relative to not participating in the federation. 
III. Analyzing Regional Impacts of Policies Using An Applied General Equilibrium Model of Canada

Because of the above difficulties listed with the balance sheet approach, we suggest that regional gains and losses from national policies be explored using explicit numerical models, and here briefly describe a regional numerical general equilibrium model of Canada we have used to calculate the regional effects of national policies. A full statement of the model in algebraic form appears in Jones and whalley (forthcoming). The model is based on data for 1981 and is closely related to the applied general equilibrium models used elsewhere in the literature to analyze taxation and international trade policy issues (see shoven and whalley (1984)).

The model's main features are summarized in Table 1.2 It is a static single period equilibrium model in which six regions (Atlantic Canada, Quebec, Ontario, Manitoba/Saskatchewan. Alberta, and British Columbia) are specified, each with a demand and production structure. A seventh region represents the rest of the world (ROW), with whom all Canadian regions engage in international trade. Both interregional and international trade in commodities occurs. Further interactions occur between regions (such as intergovernmental transfers), and the assumption

2 The model operates both in basic variant form, and with a series of extensions which each enhance the modeling capability, but at a cost in terms of computational complexity. These extensions are discussed both in Jones and whalley (forthcoming), and Whalley and Trela (1986). 
Main Eeatures of the

Canadian Regional General Equilibrium Model

1. Regional Structure:

2. Production:

3. Demands :

4. Taxes and Transfers:
Six Canadian Regions identified along with the rest of the world (Atlantic Canada, Quebec. Ontario, Manitoba/Saskatchewan. Alberta, B.C.).

Each of six regions in Canada produces 13 goods using both primary factors and intermediate products as inputs. Thirteen goods are also produced abroad. Eacin of the 13 goods is assumed qualitatively different both across regions and internationally (Armington Assumption)

Einal demands in each region are derived by maximizing a five-level nested CES/LES utility function subject to a regional budget constraint. Intermediate demands reflect cost minimization across sources of supply.

Both regional and federal levels of government are identified, each with taxes and expenditures. Intergovernmental transfers are incorporated.

5. Model Treatment of Eactor Mobility:

(i) capital - variant (a) capital is interregionally and services intersectorally mobile, but internationaily immobile.

- variant (b) capital is interregionaliy. intersectorally, and internationally mobile.

(ii) labour - assumed internationally immobile, intersecservices torally mobile within any region, but interregionaliy partially mobile: labour is homogeneous across regions, but consumers have locational preference leading to partial mobility between regions (see Appendix for more details). resources- assumed internationally and intersectorally immobile. 
of interjurisdictional factor immobility commonly made in international trade models is not made.

Each Canadian region has 13 industries ${ }^{3}$, each of which produces a single output and uses both primary factors (capital services, labour services, and natural resources) and intermediate products (other commodities) as inputs. Regionally provided public services are included as one of the 13 produced goods in each region; this being the only good which is not interregionally traded. ROW also has 13 industries, but production involves only capital and labour services, with no intermediate or resource inputs.

The 13 regionally produced goods are treated as qualitatively different from similar comodities produced either in other regions or in Row. This is the "Armington assumption" (from Armington (1969)), widely used in international trade applied general equilibrium analysis. The reasons for adopting this treatment here are the same as in the international trade models; i.e., the presence of cross hauling in interregional trade (the same good being both imported and exported by the same region). This treatment also facilitates the incorporation of interregional trade elasticity parameters into the model.

3These are: agriculture; fishing and trapping: mines and quarries; food, beverages and tobacco; light manufacturing; lumber, paper and printing; metal and machinery; vehicles: energy; transportation; utilities; personal and business services; and governmen: : rvices. 
To simplify computation only two of the three factors of production (capital services, labour services, and natural resources) are assumed to be used in production in any region. Non-energy industries use only capital and labour services; energy industries use only natural resources and labour services.

Two different factor mobility assumptions are used for capital services in the model. In variant (a) capital is treated as both interregionally and intersectorally mobile within Canada, but internationally immobile. Variant (b) differs in also allowing international mobility of capital. These two model variants are used because the literature is not conclusive as to whether perfect international mobility of capital is a reasonable assumption to make for smaller countries such as Canada, even though many economists consistently use it. 4 Resource inputs are internationally and intersectorally immobile, entering as inputs in oil and gas (energy) industries, especially in the resourcerich regions of western Canada.

In contrast, labour is assumed to be internationally immobile, intersectorally mobile, and interregionally partially mobile. Within any region, a distribution of individuals who vary by their intensity of locational preference is assumed. Individuals trade off differences in real income associated with locating and working in various regions against their preference

\footnotetext{
${ }^{4}$ See the discussion in Feldstein and Horoika (1980), and Harberger $(1980)$.
} 
for remaining in their region of origin. The effect is that in response to changes in relative regional incomes, only a portion of any region's population migrates (see the more detailed discussion in Jones and Whalley (forthcoming)).5

This partial mobility treatment is used for a number of reasons, the most important being that a model in which labour is assumed perfectly mobile between regions is not particularly useful in analyzing whether, and by how much, regions gain or lose as a result of changes in national policies. This is because regions, as such, are not well defined. Similarly, treating. labour as completely immobile between regions allows interregional distributional effects of taxes to be analyzed, but excludes all efficiency issues associated with the regional movement of labour. 6

Products produced both within and outside a region appear in final demand functions for residents of each region, including Row. Final demands reflect utility maximization, with residents maximizing nested CES/LES utility functions subject to a budget constraint. Intermediate demands, which reflect nested CES intermediate requirement functions, are based on cost

${ }^{5}$ Furthermore, because of this treatment, when reporting model results showing regional impacts of policy changes one needs to distinguish between the original residents of a region who remain after a policy change, the original residents of a region including those who migrate outward following a policy change, and the remaining residents plus new arrivals.

${ }^{6}$ See, for instance, Boadway and Flatters (1982). 
minimization across within-region and out-of-region sources of supply. These nesting structures also facilitate the incorporation of key elasticity parameters into the model, including those which affect both interregional and international trade. Budget constraints of residents within a region include capital, labour, and resource income received by residents of the region, along with intergovernmental transfers received from the federal government and federal government transfers to persons. Taxes levied within a region enter consumer budget constraints on the expenditure side.

In the absence of data on interregional patterns of asset ownership in Canada (or any other country to our knowledge), we make the strong assumption that in the base (pre-policy change) situation considered by the model, all capital and resource income originating in a region accrues to residents of that region. Thus, one of the deficiencies of conventional balance sheet analysis listed earlier, i.e. its inability to take into account interregional asset ownership, is not addressed by our model because of data deficiencies.

External sector balance appears as part of the model equilibrium conditions. The value of imports plus the net imbalance on the capital account is equal to the value of exports. As a country then, Canada is always on its budget constraint in its international transactions. The values chosen for elasticities of substitution between canadian and foreign products in demands in each region, and the size set for ROW, jointly determine the 
international import and export price elasticities which regions within Canada face. The base year data on the output of each industry in the Row is set at ten times the value added in the same industry for all Canadian regions combined. This is done to reflect Canada's position viz-a-viz its largest trading partner, the U.S.

Into this treatment of production, demand, and interregional and international trade are integrated a series of both federal and regional (provincial) policies, all of which have regional effects. These are 1 isted in Table 2 along with a brief description of their model treatment.

In the case of most of the policies, the model treatment is relatively straightforward. For instance, the national tariff is treated as an ad valoren tax on imports into all regions in Canada, covering both final and intermediate demands and with rates varying across commodities. The main Canadian federal and provincial taxes which have interregional effects also appear in the model in ad valorem form. In other cases, the model treatment is more complex. This is the case with energy policies, where a number of different policy components come into play .

All these policies have interregional effects and, in addition, interact with each other. The general equilibrium approach allows these effects to be calculated, and removes the need for the strong assumptions typically used in the balance sheet approach. 


\section{Table 2}

Model Treatment of National Policies with

Interregional Effects

Federal Policies with Major Model Treatment Regional Impacts

Tariffs

Transportation Subsidies

Energy Policies
Other Federal Policies

Non tariff trade restrictions (such as textile quotas)

Regional Development Programs

Agricultural Programs

Regional Policies which affect Trade and Factor Flows between Regions

Barriers to free goods flows between regions

Capital market preferences used by regions

Eederal-Provincial Transfers
Established Programmes Einancing (EPF)
Ad valorem tax on imports (final and intermediate demands)

Subsidies on grain shipments from Western Canada

Provincial Royalties - ad valorem production costs

Price Ceilings - ad valorem consumer subsidies, ad valorem producer tax

Exploration Grants - producer subsidies

Model Treatment

Ad valorem equivalent tariff on imports

Regional subsidies to capital use by industry within regions

Agricultural output subsidies

Model Treatment

Ad valorem tariffs on imports from other regions in Canada

Subsidies to capital use within region

Model Treatment

System of federal-provincial transfers, with payments calculated using explicit formulae

Federal-provincial transfers to fund post secondary education and health care - equal per capita transfers to 
Canada Assistance

Programmes (CAP)

Taxes

Federal Taxes

Provincial Taxes all regions

Cost-shared regional transfers which partially fund welfare programmes

Model Treatment

Manufacturers' sales tax modelled as ad valorem tax on both final and intermediate purchases

Corporate taxes modelled as ad valorem taxes on capital inputs by industry by region

Progressive federal income taxes applying to income by region

Excise taxes modelled as ad valorem taxes on both final and intermediate purchases

Sales, income, and corporate taxes in each region also modelled in ad valorem equivalent form 
In specifying model parameter values, a calibration procedure similar to that in other applied general equilibrium models is used (see Mansur and Whalley (1984)). This uses model equilibrium conditions and base year equilibrium data to solve for the parameter values used in the model. This involves selecting parameters such that benchmark (or observed) equilibrium data can be reproduced as a model equilibrium solution. The base year 1981 micro consistent regional data set used in calibration is described in a recent paper by st-Hilaire and Whalley (1986).

only when the model is fully specified and a policy change incorporated is the model solved for a new equilibrium. Evaluations of the regional impacts of policies follow from pairwise comparisons between simulated (or new) equilibria and the benchmark equilibrium data to which the model is calibrated.

Elasticity estimates enter this calibration procedure by serving as identifying restrictions which allow other parameters to be calculated. Since different elasticities produce changes in other model parameters and affect model results, the selection of elasticity values is central to the model specification process.

Bour sets of key elasticities enter the calibration process: international trade elasticities (on both the import and export side), elasticities determining substitution effects between energy and non-energy products in both final demands and 
intermediate production in each region, 7 elasticities affecting interregional trade in comodities, and elasticity parameters which determine the size of interregional labour mobility effects.

International trade elasticity values are based on a compendium of estimates of trade elasticities due to stern et al. (1976). Median point estimates are used for both the Canadian import demand elasticities, and the export demand elasticities which Canada faces.

A survey of energy demand elasticities by Kouris (1982) reviews existing estimates, and produces a range of energy elasticity estimates $(-.1$ to -.5$)$ only slightly lower than that suggested by Thirsk and Wright (1977) for Canada. Estimates in this range are therefore used in specifying energy demand elasticity values in the model. other commodities appear in regional demand functions as a composite non-energy product, with substitution between the component products entering the composite. Since these are less crucial for results than other elasticities in the model, a Cobb-Douglas specification is used for this level of nesting in all regions.

There are no elasticity estimates for interregional trade in Canada since there is insufficient time series data on interregional trade flows. The approach used for setting these parameters (as in Hazeldine (1979)) is to assume that

7 The nesting structures used in the model for both final demands and intermediate production are identical. 
elasticities in interregional trade are the same as in international trade. This approach can, however, be questioned since a shares approach based on a region's share of international trade, would suggest that interregional trade elasticities would be considerably higher than international trade elasticities. Sensitivity analysis around these values is thus used.

Elasticities of substitution in value-added functions are set at 0.8 for all non-energy industries in all regions, and 0.5 for energy industries. These are a little lower than the values reported in the survey paper by Caddy (1976) and used in Piggott and Whalley (1985), Whalley (1985), and Ballard, Fullerton, et al. (1985) for non-energy industries. Identical values are used for similar industries in different regions.

Finally, in specifying labour mobility elasticities alternative values of model parameters are chosen to calibrate to various chosen elasticities of out-migration from each region with respect to interregional income differentials. 8 The base case specification involves an elasticity of 0.25 for each region.

Once specified in this way, the model can be used to compute counterfactual equilibria using the Newton method described in Whalley (1985). For large policy changes, computation of a counterfactual equilibrium can require large amounts of execution time if labour migration elasticities are large.

${ }^{8}$ See the discussion in Whalley and Trela (1986). 
IV. Comparing Results of General Equilibrium Computations and Balance Sheets

In Table 3 , we report balance sheet calculations of the regional impacts of Canadian federal policies using the same 1981 data used in the general equilibrium model. Two different cases are considered. The first involves all federal policies. including federal expenditure programs and taxes, while the second involves only non-energy federal policies. The reason for considering these separately is the major role played by energy policies for energy-rich regions in the 1981 base year data which is used.

The balance sheet analysis in panel A of Table 3 shows the major gainer from these policies to be Atlantic Canada, with significant benefits also accruing to other lower income regions -- Quebec and Manitoba/Saskatchewan. Substantial losses are incurred by the resource-rich western provinces. A similar picture emerges from panel B, but with the exclusion of energy policies the regional impacts against Alberta are somewhat smaller.

In Table 4 the regional balance sheet calculations for all federal policies are compared to general equilibrium calculations of the regional impacts of federal tax, transfer, and expenditure programs. As can be seen from the results, the general equilibrium calculations produce significantly different results. The losses from the elimination of all federal policies are smaller for Atlantic Canada. Manitoba/Saskatchewan, and Quebec. 


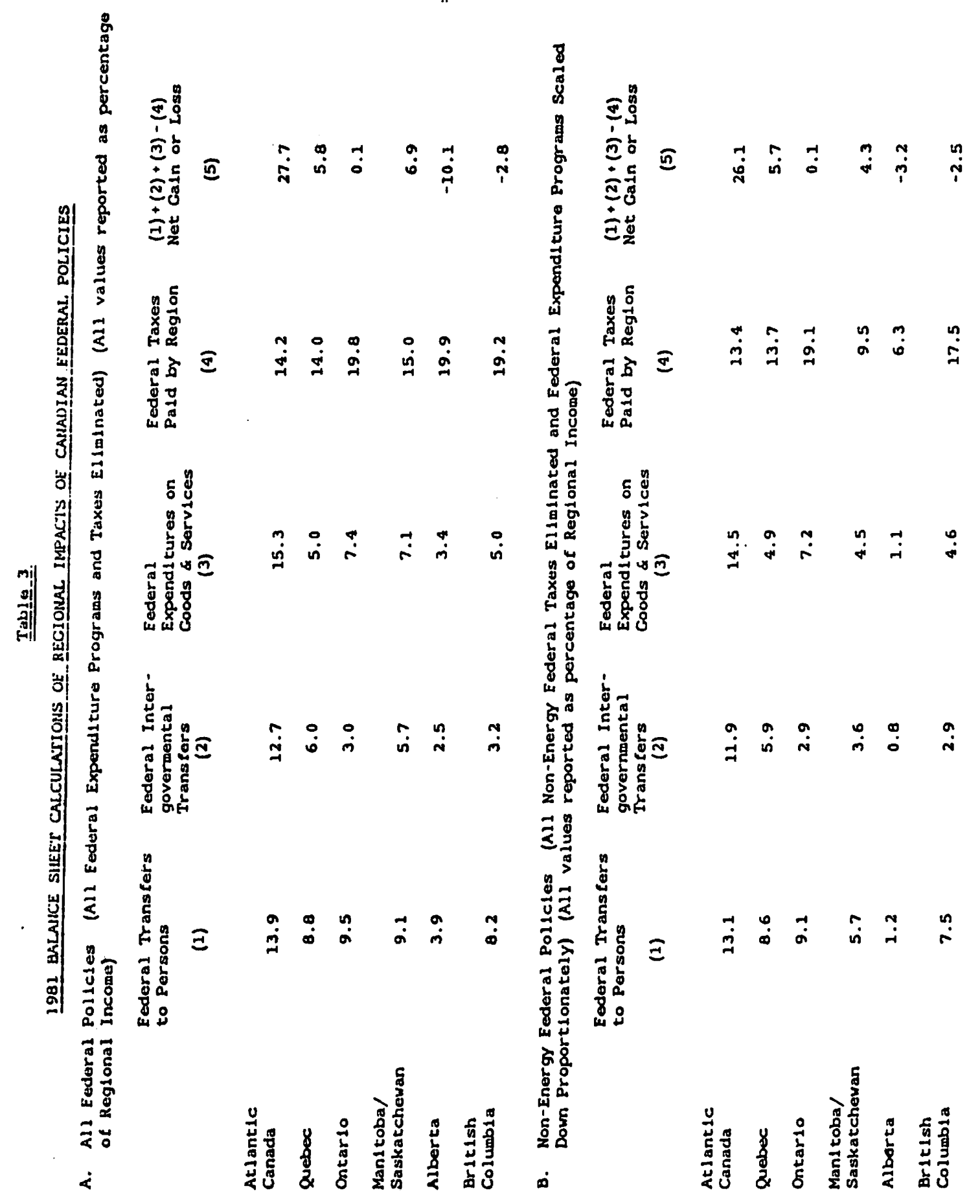


Table 4

COMPARING BALANCE SHEET CALCULATIONS TO GENERAL EQUILIBRIUM CALCULATIONS

(Regional Gains or Losses Expressed as Percentages of Regional
Incomel)

A. All Federal Policies

Balance Sheet Assessment of Regional Impacts of Removing all Federal. Policies

\author{
General Equilibrium \\ Calculation of Regional \\ Impacts of Removing all \\ Federal Tax \& Expenditure \\ Programmes
}

$$
\begin{array}{r}
-17.4 \\
-3.8 \\
+6.1 \\
-4.5 \\
+17.0 \\
+8.8
\end{array}
$$

B. Non-Energy Federal Policies

\begin{abstract}
Balance Sheet Assessment of Regional Impacts of Eliminating All Federal Non-Energy Taxes with a Proportional Reduction in Federal Expenditure Programmes
\end{abstract}

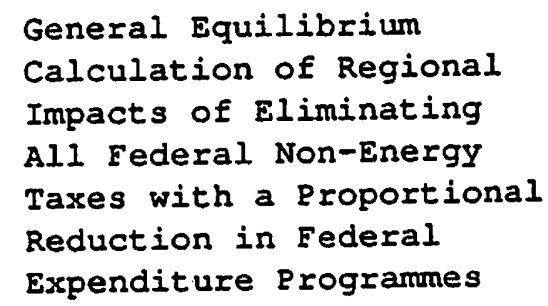

Atlantic

Canada

Quebec

Ontario

Manitoba/

Saskatchewan

$$
-26.1
$$$$
-5.7
$$$$
-0.1
$$

$-4 \cdot 3$
$-15.2$

$$
-2.9
$$

$+5.4$

$-4.2$ 

Alberta
$+3.2$
$+7.8$
British
Columbia
$+2.5$
$+7.7$
IFor the general equilibrium calculations, regional gains and losses are measured in terms of Hicksian equivalent variations. 
In contrast to the small loss shown under the conventional balance sheet approach, ontario gains approximately six percent of income, and the gains to Alberta and British Columbia are much larger. The smaller losses to losing regions and larger gains to gaining regions emphasize the inadequacy of the zero-sum game assumption implicit in balance sheets. Similar discrepancies also arise for the analysis of non-energy federal policies under panel B in Table 4.

Table 5 reports impacts on different regional groups for a case where all federal non-energy tax, transfer and subsidy programmes are replaced by a yield-preserving subsidy. Results are reported for the original residents of each region, the original residents less those who leave, and original residents less those who leave plus those who arrive. Even though the differences involved are small, this table indicates the capability of the approach in taking these differences into account. The fourth column indicates the percentage of original residents who leave as a result of the policy change for the elasticity specification used for the central case of the model.

Table 6 explores the sensitivity of model results to different elasticity parameter values for the same case considered in Table 5. The use of high interregional or international trade elasticities does not have a major impact on results. More sensitivity of results occurs with respect to migration elasticities. 


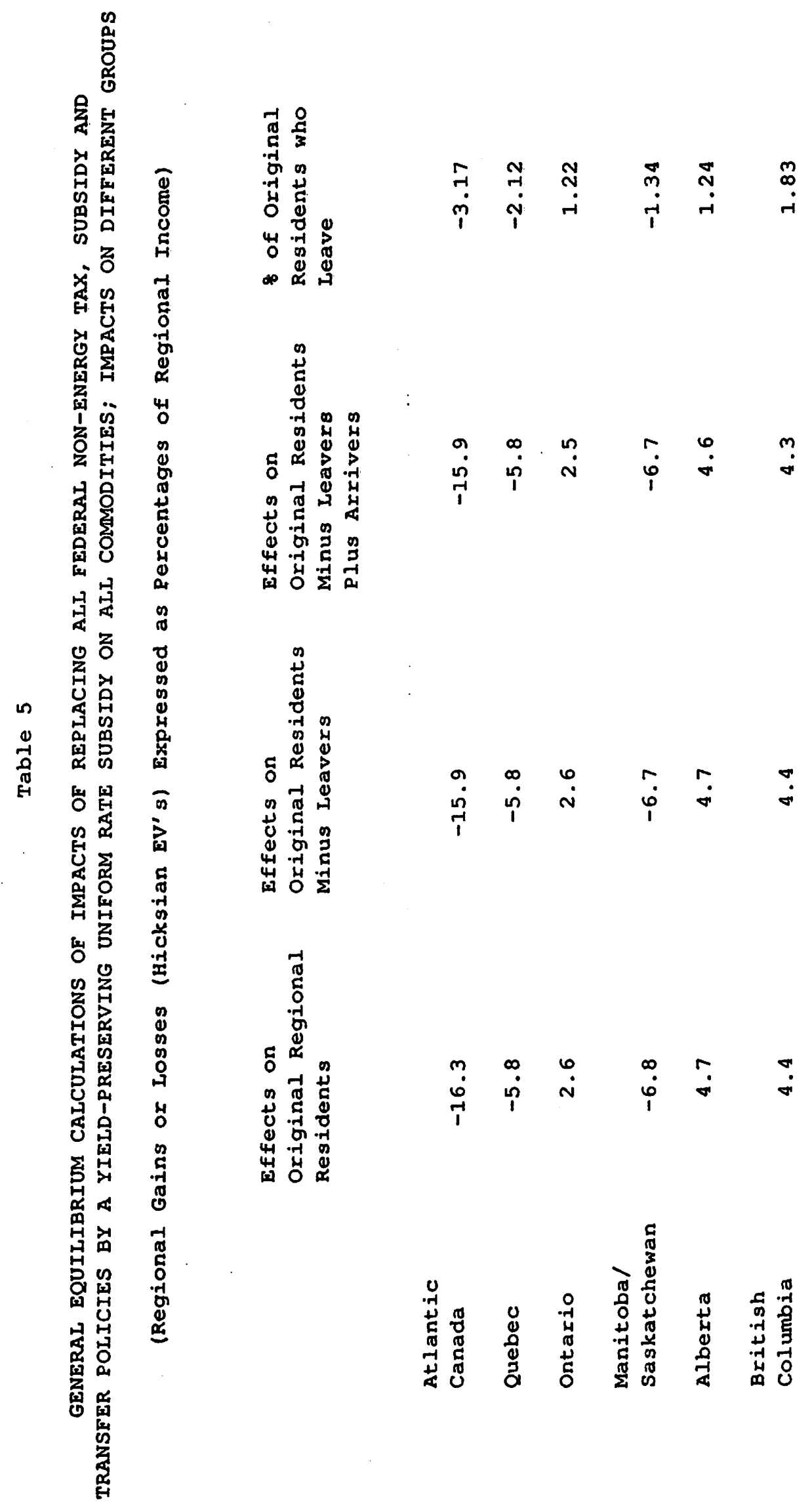




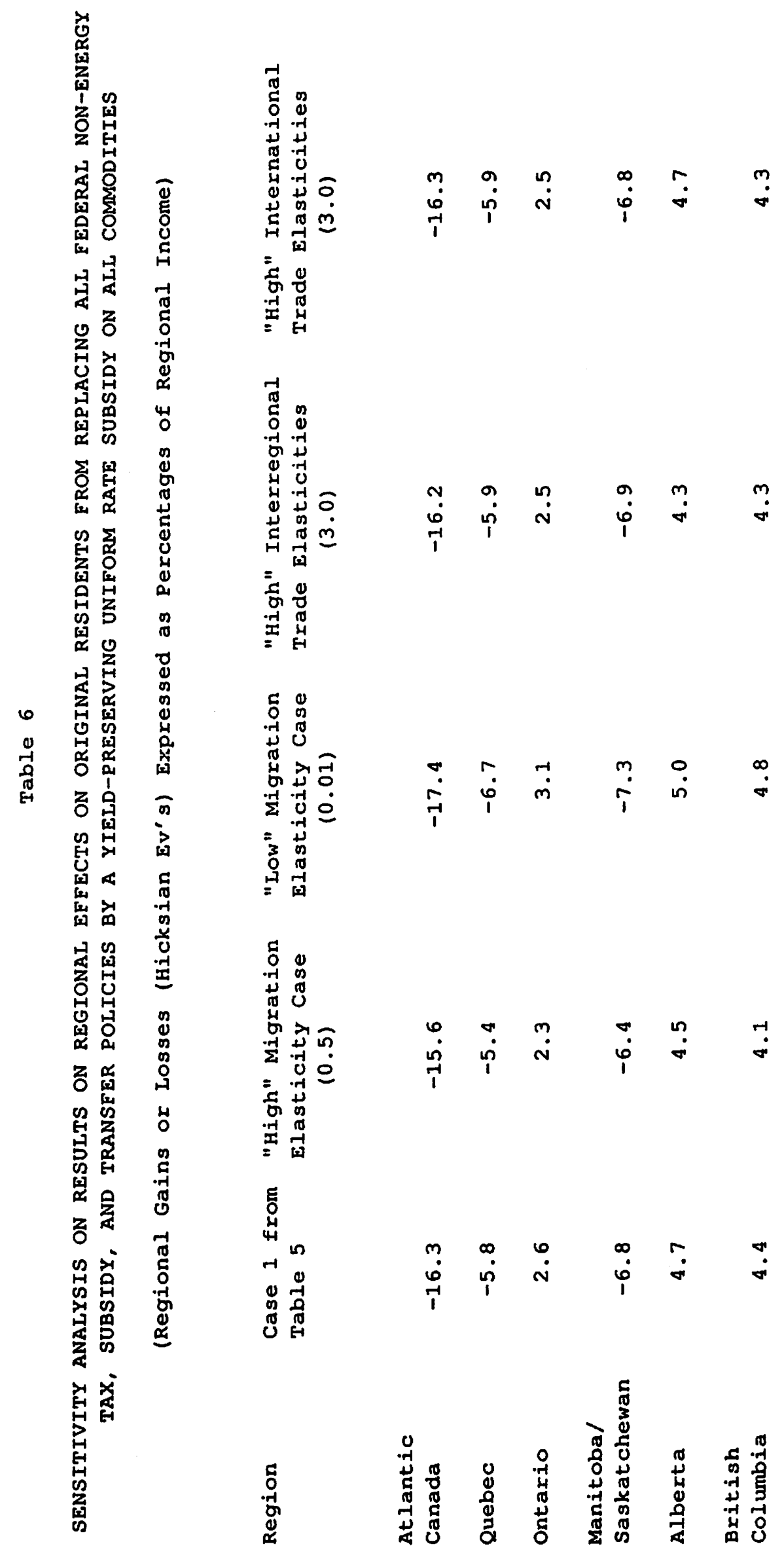


Finally, Table 7 reports the regional effects produced by the model under withdrawal by various regions from Confederation. These results emphasize the differences in the evaluation of regional impact with respect to the point of comparison. Column 1 indicates, for instance, that withdrawal by Atlantic canada from Confederation would cost the region approximately 25 percent of net income, but yield substantial net gains to all other regions. A loss is implied for all six regions, but a gain occurs for those who remain. Interestingly, in the case of withdrawal from Confederation by ontario, major losses occur for all other regions, emphasizing the substantial benefits created for all other regions by the presence of the larger region (Ontario) in Confederation. It also emphasizes how the removal of a region, in this case ontario, from Confederation does not. define a zero-sum game and that the point of comparison signiflcantly affects evaluations of regional gain or loss. 


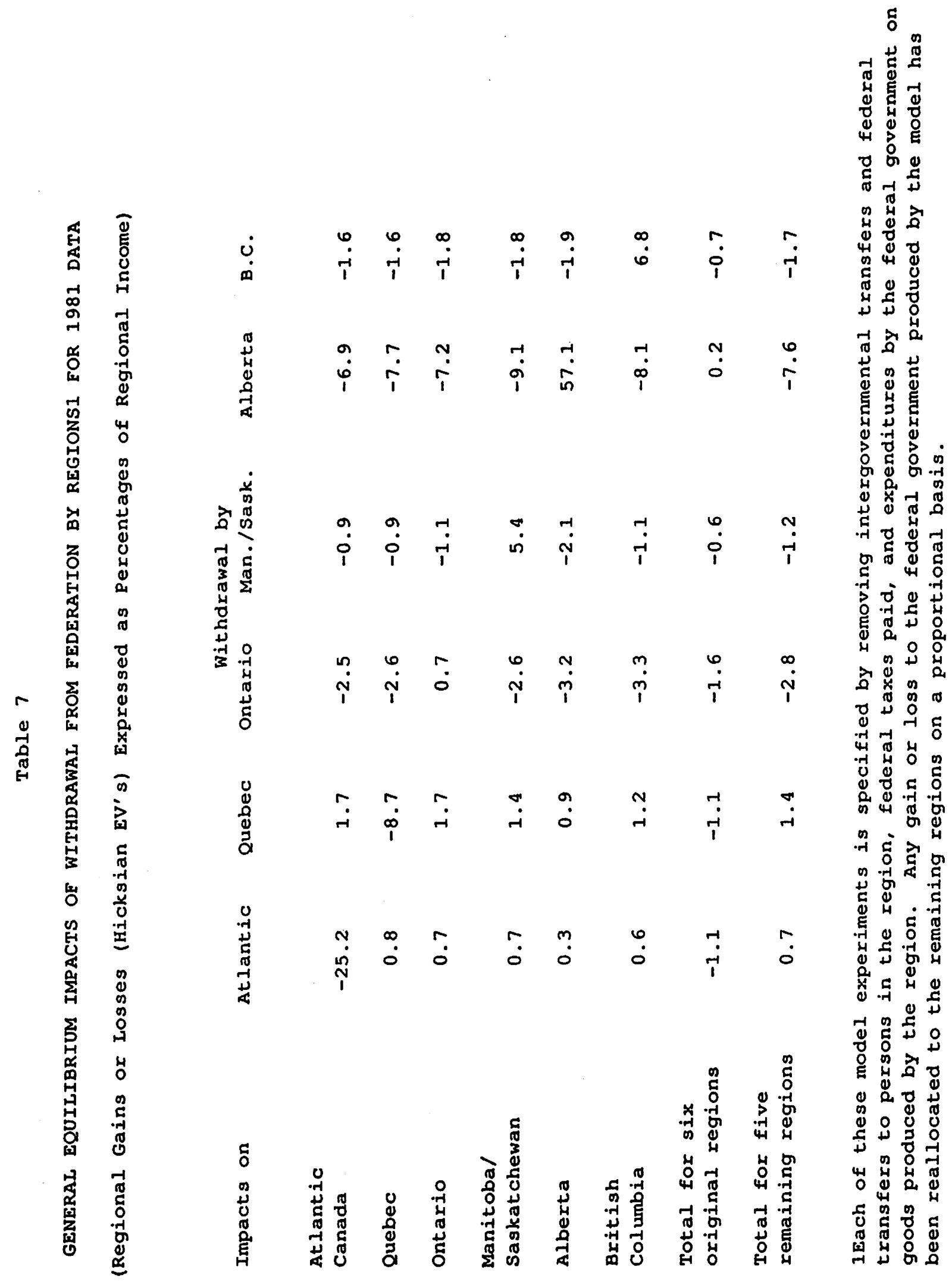


19

VI. Concluding Remarks

In this paper we present an applied general equilibrium

model of Canada which we use to analyze the regional impacts of

different policies in Canada. We contrast its results to balance

sheet measures of policy impact. Differences in results between

the conventional balance sheet and the general equilibrium

calculations are emphasized, and show how various features which

are either ignored or inappropriately treated under a balance

sheet type approach can affect evaluations of regional policy

impacts. 
BIBL IOGRAPHY

Armington, P.S. 1969. "A Theory of Demand for Products

Distinguished by Place of Production." International

Monetary Fund Staff Papers XVI: 159-76.

Ballard, C., D. Fullerton, J. Shoven and J. Whalley. 1985 .

General Equilibrium Analysis of U.S. Tax Policy. Chicago:

University of Chicago Press for the National Bureau of Economic Research.

Boadway, R.W. and F.R. Flatters. 1982. Equalization in Federal State: An Economic Analysis. A study prepared for the Econom: Cuncil of Canada. Ottawa: Minister of Supply and Services Canada.

Caddy, V. 1976. "Empirical Estimation of the Elasticity of Substitution: A Review." Industries Assistance Commission. Melbourne, Australia. (Mimeographed.)

Canada. Royal Commission on Dominion-Provincial Relations .

1940. (Rowell-sirois Commission). Report. Ottawa: King's Printer.

Feldstein, M. and C. Horoika. 1980. "Domestic Saving and International Capital Flows." Economic Journal 90 (June): $314-29$.

Harberger, A.C. 1980. "Vignettes on the World Capital Market." American Economic Review 70 (May): 331-37.

Hazledine, T. 1979. "The Economic Costs and Benefits of the Canadian Federal customs Union." In The Political Economy of Confederation. Proceedings of a joint workshop sponsored 
by the Institute of Intergovernmental Relations (Queen's University), and the Economic Council of Canada. Ottawa: Yins ster of Supply and Services Canada.

Jones, R. and J. Whalley. "A Canadian Regional General

Equilibrium Model and Some Applications". Journal of Urban Economics. (forthcoming).

Kour1s, G. 1982. "Energy Demand Elasticities in Industrialized

Countries: A survey." A paper drafted on the basis of background material collected for the demand chapter of the World Energy outlook, IEA, October.

Leslie, P. and R. Simeon. 1977. "The Battle of the Balance Sheets". In Must Canada Fail? edited by Richard Simeon. McGill-Queen's University Press.

Mackintosh, W.A. 1939. The Economics Background of Dominion-

Provincial Relations. Ottawa: J.D. Patenaude.

Mansur, A., and J. Whalley. 1984. "Numerical Specification of

Applied General Equilibrium Models: Estimation, Calibration and Data." In Applied General Equilibrium Analysis,

pp. 69-127. Edited by Herb Scarf and John Shoven.

Cambridge: Cambridge University Press.

Piggott, J.R. and J. Whalley. 1985. Applied General Equilibrium

Analysis of U.K. Tax Policy. Cambridge: Cambridge

University Press.

St-Hilaire, F, and J. Whalley. 1985. "A Microconsistent

Equilibrium Data set for Canada for Use in Regional General Equilibrium Policy Analysis." Centre for the study of 
International Economic Relations, University of Western

ontario. and forthcoming in the Review of Income and

Wealth.

Shoven, J.B. and J. Whalley. 1984. "Applied General Equilibrium Models of Taxation and International Trade." Journal of

Economic Literature XXII (September): 1007-51.

Statistics Canada. 1983a. National Income and Expenditure

Accounts, 1968-82. Cat. No. 13-201. Ottawa: Minister of

supply and Services Canada.

Statistics Canada. 1983b. Provincial Economic Accounts,

1966-1981. Cat. No. 13-213. Ottawa: Minister of Supply

and Services Canada.

Statistics Canada. 1984. The Input-output structure of the

Canadian Economy. 1971-1980. Cat. No. 12-201E. Ottawa:

Minister of Supply and Services Canada.

Stern, R.M., J. Francis, and B. Schumacher. 1976. Price

Elasticities in International Trade: An Annotated Biblio-

graphy. London: MacMillan, for the Trade Policy Research

Centre.

Thirsk, W.R., and R.R. Wright. 1977. "The Impact of the Crude

Oil Subsidy on Economic Efficiency in Canada." Canadian

Public Policy 3 (Summer): 355-64.

Whalley, J. 1985. Trade Liberalization Among Major World

Trading Areas. Cambridge: MIT Press.

Whalley, J. and I. Trela. 1986. Regional Aspects of

Confederation. Volume 68 for the Royal Commission on the 
Economic Union and Development Prospects for Canada. Toronto: University of Toronto Press. 
8501C Greenwood, Jeremy and Kent P. Kimbrough. FOREIGN EXCHANGE CONTROLS IN A BLACK MARKET ECONOMY.

8502C Horstmann, Ignatius and James R. Markusen. UP YOUR AVERAGE COST CURVE: INEEFICIENT ENTRY AND THE NEN PROTECTIONISM.

8503C Gregory, Allan W. TESTING INTEREST RATE PARITY AND RATIONAL EXPECTATIONS TOR CANADA AND THE UNITED STATES.

$8504 \mathrm{C}$ Kuhn, Peter and Ian Hooton. INTERNATIONAL FACTOR MOVEMENTS IN TIE PRESENCE OF A FIXED FACTOR.

8505C Wong, Kar-ylu. GAINS FROM GOODS TRADE AND FACTOR MOBILITY.

8506C Heller, Paul and Makoto Yano. FUTURES MARKETS, REAL INCOME, AND SPOT PRICE VARIABILITY: A GENERAL EQUUIIIBRIUM APPROACH.

8507C Dlewert, H.E. THE EFFECTS OF AN INNOVATION: A TRADE THEORY APPROACH.

8508C Ethier, Wilfred J. FOREIGN DIRECT INVESTMENT AND THE MULTINATIONAL FIRM.

8509C Dinopoulos, E11as. INSIDE THE BLACK BOX: (IN) TANGIBLE ASSETS, INTRA-INDUSTRY INVESTMENT AND TRADE.

8510C Jones, Richard, John Whalley, and Randall Higle. REgIONAL IMPACTS OF TARIFFS IN CANADA: PRELTMINARY RESULTS FROM A SMALL DIMENSIONAL NUMERICAL GENERAL EỌUIL IBRIUMY MODEL.

8511C Whalley, John. HIDDEN CHALLENGES IN RECENT APPLIED GENERAL EQUILIBRIUM EXERCISES.

8512C SmIth, Bruce. SOME COLONIAL EVIDENCE ON TWO THEORIES OF MONEY: MARYLAND AND THE CAROLINAS.

9513C Grossman, S.J., A. Melino, and R.J. Sh1ller. ESTIMATING THE CONTINUOUS TIME CONSUMPTION BASED ASSET PRICING MODEL.

8514C Romer, Paul R. TAX EFFECTS AND TRANSACTION COSTS FOR SHORT TERM MARKET DISCOUNT BONDS.

8515C McCallum, Bennett T. ON CONSEỌUENCES AND CRITJ.CISMS OF MONETARY TARGETING.

8516C Dinopoulos, Ellas and Ian Nooton. A NORTH-SOUTH MODEL OF INTERNATIONAL JUSTICE.

8517C Huffman, Gregory $W$. A DYNAMIC EQUILIBRIUM MODEL OF ASSET PRICES AND TRANSACTION VOLUME.

8518C Huffman, Gregory $W$. AN ALTERNATIVE VIEW OF OPTIMAL SEIGNIORAGE.

8519C Huffman, Gregory W. ASSET PRICING WITH HETERGENEOUS ASSETS. 
8520C Hercowitz, Zv1. THE REAL INTEREST RATE AND AGGREGATE SUPPLY.

$8521 C$ Davies, James and Michael Hoy. COMPARING INCOME DISTRIBUTIONS UNDER AVERSION TO DOWNSIDE INEQUALITY.

8522C Nguyen, Trien $T$. and John Whalley. COEXISTENCE OF EQUIIIBRIA ON BLACK AND WHITE MARKETS.

8523C Clarete, Ramon and John Whalley. INTERACTIONS BETWEEN TRADE POLICIES AND DORESTIC DISTORTIONS: THE PHILIPPINE CASE.

8524C Hamilton, Bob, Shar1f Mohammad, and John Whalley. APPLIED GENERAL EQUUILIBRIUM ANALYSIS AND PERSPECTIVES ON GROWTH PERFORMANCE.

8525C Huffman, Gregory $W$. THE LAGGED EFFECTS OF POLICY ON THE PRICE LEVEL.

8526C La1dler, David. FISCAL DEFICITS AND INTERNATIONAL MONETARY INST ITUTIONS.

8527C Goodfriend, Marvin. MONETARY MYSTIQUE: SECRECY AND CENTRAL BANKING.

8528C Nguyen, Trien T. and. John Whalley. GENERAL EQUILIBRIUM ANALYSIS OF PRICE CONTROLS A TWO-SECTOR COMPUTATIONAL APPROACH.

8529C Heckman, James J. and v. Joseph Hotz. AN INVESTIGATION OF THE LABOR MARKET EARNINGS OF PANAMANIAN MALES: EVALUATING SOURCES OF INEQUALITY.

$8530 \mathrm{C}$ Greenwood, Jeremy and Gregory W. Huffman. A DYNAMIC EQUILIBRIUM MODEL OF INFLATION AND UNEMPLOYMENT.

8531C Freeman, Scott. INSIDE MONEY, MONETARY CONTRACTIONS, AND WELFARE.

8532C Paderanga, Cayetano Jr. and Ian Wooton. A POSITIVE VIEW OF INEANT INDUSTRIES.

$8533 \mathrm{C}$ St-H1laire, France and John Whalley. A MICROCONSISTENT DATA SET FOR CANADA FOR USE IN REGIONAL GENERAL EQUILIBRIUM POLICY ANALYSIS.

8534C Whalley, John. OPERATIONALIZING WALRAS: EXPERIENCE WITH RECENT APPLIED GENERAL EQUILIBRIUM TAX MODELS.

8535C Melv1n, James R. THE GENERAL NON-EQUIVALENCE OF TARIFFS AND IMPORT QUOTAS. 
8601C Greenwood, Jeremy and R. Preston McAfee. EXTERNALITIES AND ASYMRTRIC INFORMATION.

8602C Dinopoulos, Elias and Mordecha1 E. Krelnin. IMPORT Q̣UOTAS AND VERS: A COMPARATIVE ANALYSIS IN A THREE-COUNTRY FRAMEWORK.

8603C Clarete, Ramon and John Whalley. COMPARING THE MARGINAL WELFARE COSTS OF COMMODITY AND TRADE TAXTS.

8604C Wigle, Randy. CANADIAN TRADE LIBERALIZATION: SCALE ECONOMIES IN A GLOBAL CONTEXT.

8605C Parkin, Michael. DOMESTIC MONETARY INSTITUTIONS AND FISCAL DEFICITS.

8606C Dinopoulos, Ellas and Ian Wooton. INTERNATIONAL TRADE AND THE ACQUISITION OF SKILLS.

8607C Kawasaki, Selichi and John McMillan. THE DESIGN OF CONTRACTS: EVIDENCE FROM JAPANESE SUBCONTRACTING.

8608C Williamson, Stephen D. LIQUIDITY, BANKING, AND BANK FAILURES.

8609C Grossman, Gene M. and Carl Shapiro. COUNTERFEIT-PRODUCT TRADE.

8610C Deardorff, Alan $\nabla$. WHY DO GOVERNMENTS PREFER NONTARIFF BARRIERS?

8611C Horstmann, Ignatius and James R. Markusen. LICENSING VERSUS DIRECT INVESTMENT: A MODEL OF INTERNALIZATION BY THE MULTINATIONAL ENTERPRISE.

8612C Thursby, Jerry G. and Marie C. Thursby. BIlATERAL TRADE FLOWS, THE LINDER HYPOTHESIS, AND EXCHANGE RISK.

8613C Clarete, Ramon and John Whalley. EQUIIIBRIUM IN THE PRESENCE OF FOREIGN EXCHANGE PREMIA.

8614C Wooton, Ian. TOWARDS A COMMON MARKET: FACTOR MOBILITY IN A CUSTOMS UNION.

8615C St-Hilaire, France and John Whalley. SOME ESTIMATES OF TRADE FLOWS IN BANKING SERVICES. .

8616C Evenson, Robert E. and Cayetano Paderanga Jr. RURAL LABOUR MARKETS, TRANSACTION COST AND FERTIIITY.

8617C Fried, Joel and Peter Howitt. FISCAL DEFICITS, INTERNATIONAL TRADE AND WELFARE.

8618C Trela, Irene, John Whalley, and Randy Wigle. INTERNATIONAL TRADE IN AGRICULTURE: DOMESTIC POLICIES, TRADE CONFLICTS, AND NEGOTIATING OPTIONS. 
8619C Markusen, James R. and Anthony J. Venables. TRADE POLICY WITH INCREASING RETURNS AND IMPERFECT COMPETITION: CONTRADICTORY RESULTS FROM COMPET ING ASSUMPTIONS.

$8620 \mathrm{C}$ Hunter, Linda and James R. Narkusen. PER-CAPITA INCOME AS A DETERMINANT OF TRADE.

8621C Jones, Rich and John Whalley. A CANADIAN REGIONAL GENERAL EQUILIBRIUM MODEL AND SOME APPLICATIONS.

8622C Freeman, Scott, and Gregory W. Huffman. INSIDE MONEY, OUTPUT, AND CAUSALITY.

8623C Hamilton, Colleen, and John Whalley. DEALING WITH THE NORTH: DEVELOPING COUNTRIES AND GLOBAL TRADE NEGOTIATIONS.

8624C Williamson, Stephen D. LAISSEZ FAIRE BANKING AND CIRCULATING MEDIA OF EXCHANGE.

8625C Whalley, John. WHAT HAVE WE LEARNED FROM GENERAL EQUILIBRIUM TAX POLICY MODELS?

8626C Bhatia, Kul B. SHORT RUN AND LONG RUN IN THE THEORY OF TAX INCIDENCE.

8627C Jones, Rich, and John Whalley. REGIONAL EFFECTS OF TAXES IN CANADA: AN APPLIED GENERAL EQUILIBRIUM APPROACH.

8628C Nguyen, Trien T., and John Whalley. GENERAL EQUILIBRIUM WORLD TRADE UNDER BILATERAL QUOTAS.

8629C Clarete, Ramon L., and James A. Roumasset. THE RELATIVE WELFARE COST OF INDUSTRIAL AND AGRICULTURAL PROTECTION POLICIES USING PHILIPPINE DATA. 
8701C McMillan, John, John Whalley, and Zhu Li Jing. INCENTIVE EFFECTS OF PRICE RISES AND PAYMENT-SYSTEM CHANGES ON CHINESE AGRICULTURAL PRODUCTIVITY GROWTH.

8702C Wooton, Ian. CAPITAL, SKILLS, AND INTERNATIONAL TRADE.

8703C Ryan, Cillian. TRADE IN THE PRESENCE OF ENDOGENOUS INTERMEDIATION IN AN ASYMMETRIC WORLD.

8704C Kennan, John and Raymond Riezman. OPTIMAL TARIFF EQQUILIBRIA WITH CUSTOMS UNIONS.

8705C Feenstra, Robert C., and Tracy R. Lewis. NEGOTIATED TRADE RESTRICTIONS WITH PRIVATE POLITICAL PRESSURE.

8706C Brecher, Richard A. POLICY-INDUCED INFLOWS OF FOREIGN CAPITAL IN THE PRESENCE OF RIGID-WAGE UNEMPLOYMENT.

8707C Harrison, Glenn W., Richard Jones, Larry J. Kimbell, and Randall Wigle. HOW ROBUST IS APPLIED GENERAL EQUILIBRIUM ANALYSIS?

8708C Jones, Rich and John Whalley. REGIONAL BALANCE SHEETS OF GAINS AND LOSSES FROM NATIONAL POLICIES. 